\title{
PASUKAN POLIS DALAM MEMELIHARA KESELAMATAN PENDUDUK DI PERAK, 1948-1960
}

\section{THE POLICE FORCE IN SAFEGUARDING THE SAFETY OF RESIDENTS IN PERAK, 1948-1960}

\author{
Cheang Fook Hong \\ Ho Hui Ling \\ Universiti Malaya (UM)
}

\begin{abstract}
Abstrak
Sepanjang zaman darurat dari tahun 1948 sehingga 1960, pasukan polis di Tanah Melayu bertungkus lumus dalam memerangi keganasan komunis agar dapat mengekalkan keamanan. Ekoran daripada itu, bebanan dan tanggungjawab pasukan polis telah bertambah pada zaman darurat ekoran turut bertanggungjawab untuk memerangi gerakan bersenjata komunis pada masa yang samat. Sebelum itu, pasukan polis hanya menumpukan fokus mereka dalam menyelesaikan kes jenayah yang berlaku di Tanah Melayu. Bagi menghadapi ancaman komunis dan penyokong komunis di seluruh Tanah Melayu termasuk Perak, kerajaan telah mengambil langkah dengan memperbesarkan kekuatan pasukan polis dengan penubuhan pelbagai cawangan dan unit pasukan polis pada awal zaman darurat. Cawangan dan unit yang diwujudkan oleh pasukan polis untuk memerangi ancaman komunis di Tanah Melayu termasuk Perak adalah seperti Konstabel Khas, Polis Bantuan, Home Guard, Polis Wanita, Cawangan Khas, Flying Squad, Skuad Hutan, Kompeni Hutan, Pasukan Polis Hutan dan Senoi Praaq. Pasukan polis ditempatkan di kawasan penempatan penduduk di Perak. Kehadiran pasukan polis bukan sahaja dapat melindungi keselamatan penduduk, tetapi juga dapat mengelakkan penduduk daripada menyalurkan maklumat pergerakan pasukan polis, bekalan makanan dan ubat-ubatan kepada komunis. Selain itu, pasukan polis juga ditugaskan di kawasan estet dan lombong bagi menghadapi serangan komunis di Perak. Keselamatan pengangkutan kereta api juga menjadi tanggungjawab pasukan polis. Operasi keselamatan turut dilancarkan oleh pasukan polis di kawasan pedalaman dan hutan di Perak untuk menghapuskan tempat penyembunyian komunis. Artikel ini meneliti sejauh mana penglibatan pasukan polis dalam memelihara keselamatan penduduk di Perak pada zaman darurat (1948-1960). Justeru, artikel ini bertujuan untuk melihat sejauhmana tugas pasukan polis bagi memelihara keselamatan penduduk di Perak daripada ancaman komunis. Artikel ini disempurnakan dengan menggunakan kaedah penyelidikan perpustakaan secara kualitatif dan kuantitatif. Kaedah temubual turut digunakan bagi melengkapkan tulisan ini. Penulisan ini dilakukan dengan merujuk sumber primer dan sekunder yang diperoleh daripada Arkib Negara Malaysia, Perpustakaan Universiti Malaya dan Ibu Pejabat Polis Diraja Malaysia.
\end{abstract}

Kata Kunci: Polis, Komunis, Perak, Darurat, Tanah Melayu 


\section{Abstract}

During the emergency period from 1948 to 1960, the police force in Malaya worked tirelessly in the fight against communist in order to maintain security. As a result, the burden and responsibility of the police force increased during the emergency as it was responsible for combating communist armed movements at the same time. Before the emergency, the police concentrated their focus in solving crimes that occurred in Malaya. To face the threat of communism and communist sympathizers in Tanah Melayu including Perak, the government has taken steps to expand the power of the police force with the establishment of various branches and units of the police force at the beginning of the emergency. Branches and units set up by the police force to combat the threat of communism in Malaya, including Perak such as Special Constables, Auxiliary Police, Home Guard, Police Women, Special Branch, Flying Squad, Jungle Squad, Jungle Company, Police Field Force and Senoi Praaq. Police forces were stationed in the Perak area. The presence of the police force not only protects the safety of the people, but also prevents the villagers from passing information on the movement of the police force, food supplies and medicines to the communists. In addition, police forces were also deployed to the estates and mines to counter communist attacks in Perak. Rail transport safety is also the responsibility of the police force. Security operations were also carried out by police forces in the inland area and forests of Perak to clear the communist hideout. This article examines the extent of the involvement of police forces in safeguarding the safety of Perak residents in the emergency period (1948-1960). Therefore, the purpose of this article aims to discuss the task undertaken by the police force to protect the people of Perak from communist threats. This article is completed using qualitative and quantitative library research methods. Interview methods are also used to complete this paper. The article is written based on primary and secondary sources from National Archives of Malaysia, University of Malaya Library and Royal Malaysia Police Headquarter.

Keywords: Police, Communist, Perak, Emergency, Malaya

\section{Pengenalan}

Ancaman komunis telah menyebabkan darurat diisytiharkan di Tanah Melayu pada Jun 1948. Perak, antara negeri Melayu yang turut menjadi tumpuan gerakan komunis pada ketika itu. Terdapat beberapa sebab yang mengakibatkan komunis menjadikan Perak sebagai negeri penting dalam gerakan mereka. Keadaan muka bumi di Perak yang mempunyai hutan tebal dan banjaran gunung batu kapur menggalakkan pergerakan komunis yang tersembunyi daripada pasukan keselamatan. Kepadatan penduduk Cina di Perak susulan daripada perkembangan sektor perlombongan dan perladangan juga merancakkan perkembangan pengaruh dan aktiviti komunis. Pihak komunis mendapatkan bekalan dan maklumat daripada keluarga, saudara mara dan kawan di pinggir kampung sebelum kembali ke dalam hutan.

Pada zaman darurat, penduduk menjadi sasaran keganasan komunis kerana komunis menganggap penduduk yang tidak menyokong perjuangan mereka sebagai musuh. Mereka melakukan keganasan dan membunuh orang awam, peladang, pelombong dan orang Eropah. Komunis melakukan jenayah ke atas orang awam seperti membunuh, mendatangkan kecederaan, merompak, memeras ugut dan menculik. Kekerapan kejadian jenayah pada awal zaman darurat adalah tinggi. Hal ini disebabkan gerakan bersenjata komunis sengaja mewujudkan suasana huru-hara dan tidak aman di Perak dan di seluruh Tanah Melayu. Mereka juga bertindak memusnahkan harta awam di kawasan bandar dan luar bandar di Perak. Komunis melakukan kekejaman ke atas 
penduduk di Perak tanpa mengira bangsa, agama, jantina dan umur. Tindakan komunis mengakibatkan kehidupan penduduk di Perak tergugat. Selain itu, serangan komunis ke atas estet dan lombong di Perak membawa kemusnahan kepada ekonomi. Kemudahan infrastruktur di Perak juga tidak ketinggalan disabotaj oleh komunis.

Kekuatan pasukan keselamatan di Persekutuan Tanah Melayu sebelum pengisytiharan darurat adalah seramai 9,000 orang polis dan 10 batalion askar. ${ }^{1}$ Sebaliknya, Parti Komunis Malaya (PKM) mempunyai kekuatan melebihi pasukan keselamatan iaitu lebih kurang 12,500 orang komunis. ${ }^{2}$ Pada permulaan darurat pada tahun 1948, pasukan tentera diarahkan untuk memberi bantuan kepada pasukan polis memandangkan pasukan polis kekurangan anggota dan cuma dilengkapi dengan senjata api berskala ringan. Justeru, kerajaan mengambil langkah bijak dengan memperbesarkan kekuatan pasukan polis di Tanah Melayu bagi menghadapi pemberontakan komunis. Dalam tempoh 1948 hingga 1960, pasukan polis mewujudkan pelbagai cawangan dan unit baharu bagi menggalas tanggungjawab untuk menumpaskan gerakan komunis di seluruh Tanah Melayu termasuk di negeri Perak. Antara cawangan dan unit yang diwujudkan dalam tempoh darurat bagi melawan komunis adalah seperti Konstabel Khas, Polis Bantuan, Home Guard, Polis Wanita, Cawangan Khas, Flying Squad, Skuad Hutan, Kompeni Hutan, Pasukan Polis Hutan dan Senoi Praaq.

Kebanyakan kajian lepas memfokuskan dan merangkumkan keseluruhan peristiwa darurat yang berlaku di Tanah Melayu. Walaupun, terdapat beberapa penulisan yang menyentuh sumbangan pasukan polis tetapi ianya spesifik kepada unit tertentu dan tidak memberi penekanan kepada sumbangan unit lain dalam membanteras komunis di Perak. Antaranya, hasil penulisan Yuen Yuet Leng ${ }^{3}$ yang menfokuskan kejayaan Cawangan Khas dalam menumpaskan komunis di Perak. Selain itu, kajian oleh Mohd Razali bin Ya'acob@Jusoh ${ }^{4}$ cuma memfokuskan kepada pasukan Home Guard di Perak. Justeru itu, artikel ini akan melihat sejauhmana tanggungjawab yang dijalankan oleh pasukan polis dalam memelihara keselamatan penduduk di Perak pada zaman darurat. Kajian ini dapat menonjolkan penglibatan pasukan polis di kawasan penempatan penduduk di bandar dan luar bandar, estet, lombong, kawasan pedalaman dan hutan dalam memelihara keselamatan penduduk di Perak.

\section{Langkah-Langkah Pasukan Polis Dalam Menghadapi Ancaman Komunis di Perak}

\section{Kawalan dan Pemeriksaan Keselamatan Di Kawasan Penempatan Penduduk}

Pihak komunis mendapat sokongan daripada penduduk melalui organisasi komunis yang dikenali sebagai People's Movement atau Min Yuen. ${ }^{5}$ Secara teorinya, ianya merupakan organisasi terbuka yang diwujudkan untuk menggantikan kawalan komunis ke atas kesatuan sekerja yang diharamkan selepas pengisytiharan darurat. Pada amnya, Min Yuen berperanan mengumpul dan menyalurkan dana, bekalan keperluan, maklumat kepada komunis serta menyebarkan propaganda komunis untuk merekrut penyokong baharu. Bagi menyekat penyebaran fahaman komunis dalam kalangan penduduk, Cawangan Khas ditugaskan bagi mengesan dan menjejaki Min Yuen yang bersembunyi dalam kalangan penduduk kampung. ${ }^{6}$ Penduduk kampung yang terlibat dengan aktiviti Min Yuen boleh dikenal pasti oleh pemberi maklumat. ${ }^{7}$ Pemberi maklumat merupakan orang awam yang memaklumkan maklumat berkaitan pergerakan komunis sekiranya dikesan oleh mereka. ${ }^{8}$ Sebagai contoh, pendedahan oleh pemberi maklumat berjaya mengesan penularan pengaruh komunis di sekolah Cina. Hal ini menyebabkan pihak sekolah juga tidak terlepas dari pengawasan oleh 
Cawangan Khas. Pada 5 Mac 1952, Cheah Ket Foo yang merupakan Guru Besar di Sekolah Siew Chai dan Sekolah Kampung Baru Bali, Tronoh berjaya ditangkap kerana menyebarkan fahaman komunis. Pergerakan beliau diperhatikan selama beberapa bulan sebelum membawa kepada penahanannya. ${ }^{9}$ Selain itu, Konstabel Khas, Polis Bantuan, Polis Wanita dan Home Guard di bawah pentadbiran pasukan polis di Perak juga ditugaskan di kawasan penempatan penduduk bagi memastikan kelancaran pelaksanaan dasar kerajaan untuk menjaga keselamatan penduduk di samping meringankan beban polis tetap. Hal ini bagi membolehkan polis dapat menjalankan operasi menjejaki dan menghapuskan komunis di dalam hutan.

Rajah 1: Home Guard memeriksaan kenderaan keluar masuk di Kampung Baru untuk menghalang bekalan makanan daripada sampai ke tangan Komunis

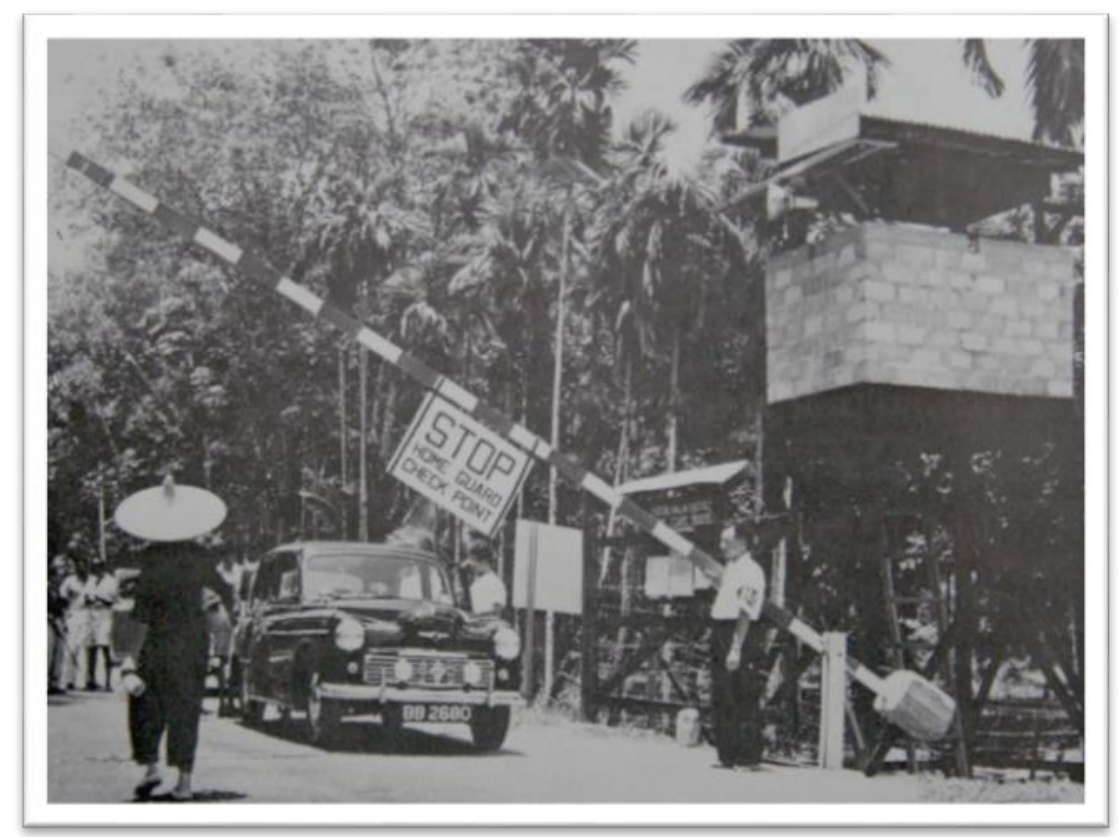

Sumber: Muzium Polis Diraja Malaysia

Sehingga tahun 1958, seluruh Tanah Melayu mempunyai sebanyak 558 buah kampung baru dan Perak sahaja mempunyai sebanyak 156 buah kampung baru ${ }^{10}$ seperti mana dalam Jadual 1. Pertambahan bilangan kampung baru dari tahun ke tahun menunjukkan keberkesanan rancangan penempatan semula dalam melindungi keselamatan penduduk dan mencantas pengaruh komunis. Anggota polis dan Home Guard ditempatkan di kampung baru untuk menjaga keselamatan serta memberi perlindungan kepada penduduk. Pihak komunis mengancam dan memeras ugut penduduk kampung baru, tetapi pihak polis membalas tindakan komunis dengan mempertingkatkan kawalan perlindungan ke atas penduduk. Kesannya, kejadian ancaman dan ugutan komunis ke atas penduduk semakin berkurangan. Dengan itu, penduduk mula menyalurkan maklumat kepada polis dan Home Guard. Ini kerana penduduk kampung baru mula yakin dengan suasana persekitaran yang selamat dan perasaan ketakutan terhadap komunis semakin berkurangan. ${ }^{11}$ Pada masa yang sama, sebagai langkah tambahan terhadap keselamatan penduduk di kampung baru, pemilik rumah dikehendaki menyenaraikan kesemua penghuni di rumahnya dan salinan senarai perlu diserahkan kepada pihak polis. ${ }^{12}$ Hal ini bagi memastikan tiada komunis atau orang yang disyaki yang menumpang di rumah penduduk. 
Sejarah: Journal of History Department, University of Malaya; No. 29 (1) 2020: 158-177; ISSN 1985-0611.

Jadual 1: Statistik Pecahan Kampung Baru di Tanah Melayu pada Tahun 1958

\begin{tabular}{|c|c|}
\hline Negeri & Bilangan Kampung Baru \\
\hline Johor & 130 \\
\hline Melaka & 17 \\
\hline Negeri Sembilan & 40 \\
\hline Selangor & 66 \\
\hline Perak & 156 \\
\hline Kedah & 33 \\
\hline Pulau Pinang & 9 \\
\hline Perlis & 1 \\
\hline Pahang & 79 \\
\hline Terengganu & 4 \\
\hline Kelantan & 23 \\
\hline Jumlah & 558 \\
\hline
\end{tabular}

Sumber: Ray Nyce, Chinese New Villages In Malaya: A Community Study, Singapura: Malaysian Sociological Research Institute, 1973, hlm. 4a.

Polis Bantuan juga memainkan peranan mempertahankan kawasan penempatan atau perkampungan mereka masing-masing daripada kegiatan komunis. Pada masa yang sama, mereka diberi kuasa untuk melancarkan serangan balas terhadap komunis yang menyerang penempatan mereka. Polis Bantuan mengambil alih tugas rutin polis tetap di kawasan penempatan bagi membolehkan pasukan polis tetap digerakkan untuk operasi melawan komunis di dalam hutan. ${ }^{13}$ Justeru, penduduk digalakkan untuk menyertai Polis Bantuan bagi melindungi penempatan mereka daripada ancaman komunis. Lau Pak Khuan, selaku Presiden Perak Chinese Chamber of Commerce menyeru ahlinya yang hadir dalam mesyuarat pada 13 Ogos 1948 untuk menyertai Polis Bantuan. Beliau menyatakan bahawa mereka yang terlibat cuma perlu bekerja selama empat jam dalam tempoh seminggu. Tambahan beliau, mereka yang menyertai Polis Bantuan ditugaskan di kawasan bandar untuk membolehkan pasukan polis tetap melaksanakan rondaan di luar bandar dan operasi melawan pihak komunis. ${ }^{14}$ Penglibatan Polis Bantuan dalam memerangi komunis di Perak dapat dilihat dalam kejadian yang berlaku pada 12 April 1952 di Taiping. Pada 12 April 1952, pasukan rondaan Polis Bantuan bertembung dengan lapan orang komunis di kawasan bukit berdekatan penempatan penduduk di Taiping. Namun, pasukan keselamatan tidak dapat melepaskan tembakan kerana komunis menggunakan seorang wanita Melayu dan empat orang kanak-kanak sebagai tebusan. ${ }^{15}$ Dalam pada itu, ketangkasan Polis Bantuan dalam menghadapi ancaman komunis dapat dibuktikan apabila pasukan itu berjaya menumpaskan komunis yang cuba menyerang kampung baru. Pada 13 Mei 1952, Polis Bantuan berjaya membunuh empat orang komunis ketika mereka cuba mencerobohi Kampung Bukit Sapi, Lenggong. ${ }^{16}$ Selain itu, polis Bantuan juga terlibat secara langsung dalam kempen bagi menarik minat masyarakat Cina untuk menyertai pasukan polis. Antara kempen yang diadakan oleh kerajaan di Perak adalah seperti mengadakan pertunjukan perbarisan Polis Bantuan di Padang Ipoh pada 10 April 1952. ${ }^{17}$ Langkah ini menyasarkan kawasan yang mempunyai majoriti penduduk kaum Cina seperti di Ipoh. Hal ini bertujuan untuk menggalakkan masyarakat Cina untuk menyertai pasukan polis dan mengalihkan sokongan penduduk Cina di Perak daripada terus menyokong komunis. 
Tidak dapat dinafikan juga Home Guard memainkan peranan penting dalam menjaga keselamatan penduduk di kampung baru. Bermula pada penghujung tahun 1951, setiap kampung baru yang sedia ada dan yang bakal dibina dikehendaki untuk membentuk unit Home Guard. Oleh itu, setiap kampung baru mempunyai unit Home Guard masing-masing. Home Guard diwujudkan untuk membantu meringankan beban pasukan polis dan mendidik penduduk tempatan untuk mempertahankan kampung masing-masing. ${ }^{18}$ Pengambilan Home Guard adalah daripada kalangan penduduknya untuk menggalas tanggungjawab mempertahankan keselamatan perimeter sekeliling kampung, rondaan, pertahanan dalaman kampung dan kawalan statik. Kehadiran Home Guard terlatih di kampung baru membolehkan lebih ramai pasukan polis dan pasukan tentera untuk terlibat secara aktif dalam operasi menentang komunis di dalam hutan. ${ }^{19}$ Home Guard juga berperanan untuk membantu pihak polis dalam tugas operasi kawalan makanan, pemeriksaan kad pengenalan dan pendaftaran penghuni di penempatan kampung baru. ${ }^{20}$ Kehadiran pasukan polis di kawasan penempatan penduduk bukan sahaja berjaya menjaga keselamatan penduduk, tetapi juga dapat mengekang penyebaran fahaman komunis di kalangan penduduk kampung baru dan gerakan Min Yuen di Perak.

\section{Pemeriksaan Kad Pengenalan}

Antara langkah yang diambil oleh kerajaan pada awal zaman darurat adalah memperkenalkan skim pendaftaran nasional. Sir Henry Gurney, Pesuruhjaya Tinggi Persekutuan Tanah Melayu pada ketika itu memperkenalkan skim pendaftaran nasional di mana setiap warganegara dikehendaki berdaftar untuk memperoleh kad pengenalan. Kad pengenalan mengandungi maklumat individu seperti butiran peribadi, gambar dan cop ibu jari untuk memudahkan pengecaman pihak berkuasa. Sistem pengenalan diri mengambil tempoh selama dua tahun untuk dilaksanakan sepenuhnya di Tanah Melayu. Fasa pertama dilaksanakan pada September 1948 di Pulau Pinang, Kedah dan Perlis. Pada Oktober 1948, sistem ini dilaksanakan di Kelantan, Terengganu dan Pahang. Akhirnya, seluruh Tanah Melayu termasuklah Perak menjalankan sistem pendaftaran ini pada tahun $1950 .^{21}$

Penggunaan kad pengenalan ini dapat membezakan penduduk dengan pihak komunis. Di bawah langkah ini, pasukan polis sering mengadakan pemeriksaan terhadap penduduk. Mereka yang tidak memiliki kad pengenalan akan ditahan oleh pasukan keselamatan kerana disyaki sebagai komunis. Oleh itu, komunis bertindak merampas kad pengenalan daripada penduduk. ${ }^{22}$ Antaranya, pada 27 April 1950, pasukan Skuad Hutan bertempur dengan lima orang komunis yang merampas kad pengenalan daripada penduduk di perkampungan di Batu Tujuh Jalan Bidor-Teluk Anson. Salah seorang daripada komunis itu berjaya dibunuh dan yang lain sempat melarikan diri. ${ }^{23}$ Langkah pasukan polis membuat pemeriksaan kad pengenalan terhadap penduduk di Perak berjaya menimbulkan kerisauan pihak komunis. Hal ini kerana hanya rakyat Tanah Melayu sahaja yang memiliki kad pengenalan. Mereka yang diperiksa tidak memilik kad pengenalan akan ditangkap pasukan polis kerana disyaki sebagai komunis.

\section{Rondaan dan Pemeriksaan Keselamatan}

Demi memastikan komunis dan penyokongnya dihapuskan secara berkesan, kawalan dan pemeriksaan pasukan polis dijalankan dari masa ke semasa sama ada di dalam atau sekitar perimeter penempatan penduduk. Hal ini dapat dilihat pada 24 Februari 1949 apabila pihak polis membuat rondaan di kawasan pinggir perkampungan di Slim River dan bertempur dengan dua orang komunis yang cuba melarikan diri ke dalam hutan. 
Pasukan rondaan melepaskan tembakan dan mencederakan seorang komunis, manakala seorang lagi sempat melarikan diri. Komunis yang cedera itu cuba menarik bom tangan daripada tali pinggangnya apabila polis mendekatinya. Pihak polis bertindak menembak mati komunis itu dan berjaya menemui beberapa dokumen komunis daripada badan komunis itu. ${ }^{24}$ Dalam kejadian lain pada 28 Mac 1949, pihak polis membuat pemeriksaan dari rumah ke rumah di kawasan Beting Luas, Sitiawan. Beberapa orang dilihat melarikan diri apabila polis mendekati sebuah rumah. Pasukan polis bertindak melepaskan tembakan dan dua orang komunis mengalami kecederaan dalam kejadian tersebut. Hasil tindakan polis berjaya menangkap tiga orang komunis dan menemui tujuh bungkusan yang mengandungi kelengkapan ketenteraan di dalam sebuah rumah. ${ }^{25}$

Pasukan keselamatan juga ditugaskan untuk menjalankan pemeriksaan keselamatan khas di kawasan Bandar Diraja Kuala Kangsar. Pada 15 April 1949, beberapa ratus orang polis dan tentera digerakkan untuk membuat sekatan dan pemeriksaan di semua jalan yang menghala ke kawasan Bandar Diraja Kuala Kangsar ekoran daripada maklumat yang mendedahkan ternampak sekumpulan Cina bersenjata di kawasan barat daya Kuala Kangsar. Kereta pasukan polis yang dilengkapi dengan set radio dan telefon juga dihantar ke lokasi berkenaan. Selain itu, polis turut dilengkapi walkie talkie agar dapat berhubung terus dengan balai polis ketika membuat rondaan dan pemeriksaan kad pengenalan di kawasan pejalan kaki. Polis Bantuan Melayu dan Cina diberi peranan untuk menahan mana-mana indvidu yang kelihatan mencurigakan untuk dihantar ke balai polis bagi disoal siasat. ${ }^{26}$ Pada 26 Julai 1949, operasi pemeriksaan turut dijalankan oleh pasukan polis di kawasan Jelapang-Chemor. Dalam operasi itu, pasukan polis berjaya menahan seramai 17 orang untuk siasatan lanjut. ${ }^{27}$ Selain itu, pada 2 Januari 1950, pasukan polis membuat pemeriksaan di batu 21/2, Jalan Degong, Kampar dan menahan tiga orang lelaki ekoran salah seorang lelaki itu dilihat dalam keadaan mencurigakan. Kemudiannya, kesemua mereka dibawa ke Balai Polis Kampar untuk disoal siasat. ${ }^{28}$ Dengan itu adalah jelas pasukan polis sentiasa mengambil langkah berjaga-jaga terhadap kewujudan ancaman komunis sama ada di dalam atau luar kawasan penempatan penduduk di Perak. Justeru, rondaan serta pemeriksaan pasukan polis di dalam dan luar perimeter penempatan penduduk sekali gus dapat mengesan elemen komunis yang bergerak bebas mahupun bersembunyi dalam kediaman penduduk di Perak.

\section{Kawalan Makanan}

Kerajaan juga mengambil langkah memperketatkan kawalan makanan di kawasan penempatan penduduk untuk menangani ancaman komunis. Pada Jun 1951, Sir Harold Briggs melancarkan Operation Starvation di seluruh Tanah Melayu dengan mempertingkatkan kekerapan rondaan pasukan keselamatan sehingga memaksa komunis keluar daripada tempat penyembunyian akibat kelaparan. Untuk itu, kawalan makanan diperkenalkan di kawasan operasi. Ketika operasi dilancarkan, pekedai dikehendaki menyimpan rekod inventori dan tiada pergerakan stok makanan tanpa permit kerajaan. ${ }^{29}$ Tindakan kerajaan tersebut menyebabkan tiga orang komunis mengalami kecederaan selepas berbalas tembakan dengan pasukan keselamatan ketika mereka keluar dari tempat penyembunyian untuk mencari makanan di Gerik. ${ }^{30}$ Selain itu, kerajaan memperkenalkan Dapur Pusat pada pertengahan 1954 untuk mengelakkan makanan daripada jatuh ke tangan komunis. Di Ipoh, Konstabel Khas mengiringi penghantaran beras ke Dapur Pusat untuk dimasak. Selain itu, Konstabel Khas juga dipertanggungjawabkan untuk memastikan keadaan terkawal ketika proses pengagihan nasi yang siap dimasak di Dapur Pusat di Ipoh kepada penduduk tempatan. ${ }^{31}$ 
Operasi kawalan makanan yang pertama kali dilancarkan di kawasan tengah Perak pada November 1953 dinamakan sebagai Operation Inland. Operasi kawalan makanan ini melibatkan tiga orang Polis Leftenan, 300 orang Konstabel Khas, 72 orang pemeriksa Polis Wanita dan tentera. Operation Inland adalah meliputi keseluruhan kawasan daerah Utara Sungai Siput dan sebahagian kawasan Utara Ipoh. ${ }^{32}$ Ianya dilaksanakan untuk mengelakkan sebarang makanan daripada kawasan Sungai Siput, Tanjung Rambutan dan Chemor daripada sampai ke tangan komunis. Dalam operasi ini, Dato Panglima Bukit Gantang selaku Menteri Besar Perak turut menyertai Polis Bantuan selama empat jam untuk membuat pemeriksaan makanan di Kampung Baru Kuala Kuang, Chemor pada 30 Disember 1953. Selain itu, pegawai kerajaan Negeri Perak di Batu Gajah dan Kuala Kangsar turut mendaftarkan diri sebagai Polis Bantuan bagi membuat pemeriksaan pagar dan jalan di kawasan berkenaan. ${ }^{33}$ Kerajaan melaksanakan kawalan makanan kerana selepas program penempatan semula dengan mengawal bekalan makanan seperti beras, gula, garam, minyak dan ubat-ubatan, namun, pihak komunis masih mendapat makanan melalui memeras ugut penoreh getah di ladang. ${ }^{34}$ Dalam tempoh semasa berlangsungnya Operation Inland, kumpulan komunis Melayu iaitu Regimen Ke-10 MRLA sedang dalam perjalanan dari Pahang menuju ke sempadan Thailand untuk berjumpa dengan Chin Peng, iaitu Setiausaha Agung PKM. ${ }^{35}$ Seramai 13 orang komunis dibunuh dan seorang komunis menyerah diri dalam tempoh lapan bulan berlangsungnya Operation Inland yang berakhir pada September 1954. Selain itu, seramai 141 orang penduduk ditangkap di bawah Undangundang Darurat. Antaranya, 21 orang ditahan kerana disyaki mempunyai elemen subversif atau dituduh di mahkamah dan seramai 120 orang dibebaskan selepas disoal siasat. ${ }^{36}$ Kejayaan tangkapan itu menunjukkan pasukan polis berjaya mengawal bekalan makanan dan ubat-ubatan daripada sampai ke tangan pihak komunis.

\section{Operasi Gerakan Anti-Komunis}

Pasukan polis bersama agensi lain turut melancarkan operasi besar-besaran di kawasan Perak bagi memberi tekanan kepaada pihak komunis supaya mereka keluar daripada tempat persembunyian agar dapat dihapuskan secara berkesan. Usaha pasukan polis untuk menghapuskan kumpulan komunis di Perak dapat dilihat dalam Operation Parchment. Operation Parchment yang dilancarkan pada September 1956 meliputi kawasan seluas 1,000 batu persegi di Selatan Perak dan disertai oleh lebih daripada 5,000 orang askar, polis dan Home Guard. Operasi ini mensasarkan 60 orang komunis yang bersembunyi di dalam hutan antara Slim River dan Tanjung Malim berdekatan sempadan Selangor dan Perak. Tugas utama kumpulan komunis itu adalah untuk memelihara perhubungan gerakan PKM di Selangor dengan komunis di Cameron Highlands, Pahang. Justeru, pasukan keselamatan dipertanggungjawabkan untuk menumpaskan kumpulan 60 orang komunis itu agar dapat memutuskan perhubungan antara kumpulan komunis di Selangor dan Cameron Highlands. Sementara itu, 120 orang askar, 90 orang anggota polis, 42 orang pemeriksa makanan dan sembilan buah pasukan Jabatan Penerangan menjalankan pemeriksaan di Selatan Perak untuk menyekat makanan daripada sampai ke tangan komunis. Dalam operasi ini, seramai 40,000 orang penduduk dikenakan perintah berkurung semasa pegawai kerajaan menjalankan pemeriksaan ke atas makanan dan kad catuan makanan. Setiap lelaki diperuntukkan sebanyak tiga kati beras untuk tempoh seminggu, dua kati setengah bagi wanita dan setengah kati bagi kanak-kanak di bawah umur 12 tahun. Bekalan seperti mee hon, minyak masak, ikan kering dan garam juga dicatu serta bekalan makanan yang lebih turut dirampas. Perintah berkurung dibatalkan selepas setiap kawasan itu selesai diperiksa. Anggota polis dan Home Guard juga turut menjalankan pemeriksaan mengejut $^{37}$ dari rumah ke rumah agar memastikan penduduk tidak menyimpan 
makanan melebihi had bekalan yang diperuntukkan. Operation Parchment dihentikan pada Ogos 1957 dan pasukan keselamatan berjaya membunuh lapan orang komunis dengan dua orang komunis lain menyerah diri. ${ }^{38}$

Selain itu, Operation Jaya turut dilaksanakan pada 9 Januari 1959 untuk menghapuskan komunis ${ }^{39}$ di kawasan berkeluasan 1,060 batu persegi yang mempunyai kepadatan penduduk seramai 131,000 orang. Operasi ini melibatkan kawasan daerah Kuala Kangsar, Upper Perak, Larut, Matang, Sitiawan dan Parit. ${ }^{40}$ Seramai 4,000 orang anggota keselamatan termasuk tentera, polis dan Home Guard digerakkan untuk menyingkirkan seramai 53 orang komunis yang keras hati. ${ }^{41}$ Orang awam yang berjaya menyalurkan maklumat sehingga membawa kepada penangkapan atau pembunuhan komunis akan dibayar ganjaran oleh kerajaan. Setiap komunis yang berjaya ditangkap atau menyerah diri dibayar ganjaran sebanyak \$12,000, manakala ganjaran sebanyak $\$ 10,000$ bagi setiap komunis yang dibunuh. ${ }^{42}$ Selain itu, kerajaan juga menawarkan sejumlah ganjaran dari $\$ 1,000$ hingga $\$ 20,000$ kepada penduduk yang dapat menyalurkan maklumat sehingga berjaya menghapuskan komunis. ${ }^{43}$ Pada masa yang sama, penduduk di daerah Beruas diingatkan supaya bekerjasama dengan pihak kerajaan untuk menghapuskan saki-baki komunis yang berada di kawasan Operation Jaya $^{44}$ Operasi ini terbukti mengecewakan kerana sehingga Januari 1960 cuma dua orang komunis yang berjaya dibunuh secara kebetulan dalam hutan tebal oleh pasukan keselamatan dan bukannya maklumat daripada orang awam. ${ }^{45}$ Walaupun tidak semua kerjasama pasukan polis bersama agensi lain mencapai kerjayaan besar, tetapi usaha mereka dapat menakutkan pihak komunis untuk bergerak jauh ke kawasan pedalaman di Perak agar tidak bertempur dengan pasukan polis.

\section{Kawalan Keselamatan di Estet dan Lombong}

Industri getah dan bijih timah di negeri-negeri Melayu menerima kesan yang teruk daripada tindakan komunis pada zaman darurat. Industri getah mengalami kehilangan kakitangan, kemusnahan pokok getah, jentera berat dan lori di kawasan estet. Industri bijih juga mengalami kerugian yang sama dan juga susulan daripada penghentian operasi. ${ }^{46}$ Komunis menjadikan aktiviti menakik pokok getah dan merosakkan peralatan melombong sebagai sebahagian daripada kegiatan mereka. Dalam tempoh sepanjang zaman darurat, sebanyak ratusan ribu pokok getah ditakik oleh komunis di estet kecil mahupun besar di seluruh Tanah Melayu. ${ }^{47}$ Ini kerana PKM melancarkan taktik bumi hangus dengan memusnahkan ladang getah, lombong dan harta awam untuk mengganggu gugat kegiatan ekonomi di seluruh Tanah Melayu termasuk di negeri Perak. ${ }^{48}$

Pada masa yang sama, pelaksanaan rancangan penempatan semula penduduk menyebabkan komunis kehilangan bantuan bekalan dan keperluan hidup daripada penyokongnya. Hal ini menyebabkan pihak komunis beralih kepada sasaran lain iaitu pengusaha dan pekerja di estet serta lombong di Tanah Melayu termasuk di Perak. Kesannya, penduduk yang bekerja di kawasan estet dan lombong sentiasa berada dalam ketakutan kerana menjadi sasaran komunis. Sebagai contoh, dua letupan berlaku di sebuah lombong timah di Kampar pada 26 Oktober 1948 dan mengakibatkan kerosakan pada mesin jengkaut. Pada keesokan harinya, dua buah mesin jengkaut dan kediaman pekerja di Sungai Siput pula dimusnahkan oleh enam orang komunis dengan menggunakan bahan letupan. ${ }^{49}$ Selain itu, seorang pengurus Eropah terbunuh semasa diserang hendap dan ditembak oleh komunis pada 14 Julai 1950 di sebuah estet di kawasan Sungai Siput. ${ }^{50}$ Dalam kejadian lain, seorang penoreh getah dipercayai diculik oleh komunis dari Hendon Estate, Taiping pada 15 September $1953 .{ }^{51}$ Pada Jun 1954 pula, seorang pengurus dan pembantu ladang ditembak mati oleh komunis di sempadan Kamuning Estate, Perak. ${ }^{52}$ Justeru itu, Konstabel Khas, Polis Bantuan, Flying Squad 
dan Pasukan Polis Hutan dipertanggungjawabkan untuk melindungi nyawa kakitangan serta aset di estet dan lombong daripada serangan komunis. Sektor perladangan getah dan perlombongan timah adalah dua sektor ekonomi utama kerajaan British di Tanah Melayu. British amat bergantung kepada getah dan bijih timah bagi membiayai pentadbiran dan perbendaharaan Britain serta tanah jajahannya. Dengan demikian, gangguan komunis ke atas dua sektor ekonomi ini mampu menjejaskan kelancaran pentadbiran British di Tanah Melayu. Perak adalah antara negeri Melayu yang penting dari segi perladangan getah dan perlombongan timah. Justeru, kawalan keselamatan di estet dan lombong di Perak diberi perhatian oleh pentadbiran British pada zaman darurat.

Komunis melancarkan serangan untuk menimbulkan suasana ketakutan di kawasan estet dan lombong. Serangan komunis ke atas estet dan lombong adalah untuk mengganggu industri getah dan timah serta ekonomi di negara ini. Mereka turut melancarkan serangan keganasan ke atas individu yang memihak kepada kerajaan. Kebanyakan insiden sasaran serangan hendap dan pembunuhan terdiri daripada pelombong British di Perak. ${ }^{53}$ Sepanjang tempoh darurat, seramai 22 orang peladang Eropah di Perak dilaporkan dibunuh oleh komunis ${ }^{54}$ seperti mana dalam Jadual 2. Justeru, disediakan pos kawalan bagi menempatkan Polis Bantuan untuk menjaga keselamatan kakitangan di kawasan estet dan pelombongan. Polis Bantuan yang dilengkapi senjata api ditugaskan untuk mengawal di lombong dan melindungi pekerja serta pelombong. ${ }^{55}$ Bermula dari tahun 1951, pemilik dan pengurus estet serta lombong menempatkan Polis Bantuan atas perbelanjaan sendiri untuk menjaga keselamatan pekerja mereka di tempat kerja. Kemudiannya, Konstabel Khas turut digunakan untuk tujuan yang sama. ${ }^{56}$ Polis Wanita juga memainkan peranan seperti polis lelaki yang berbezanya mereka ditugaskan untuk membuat pemeriksaan ke atas wanita terutamanya penoreh getah dan pekerja lombong. ${ }^{57}$ Kewujudan Polis Bantuan sememangya dapat memberi perlindungan keselamatan di kawasan lombong dan estet kerana pasukan itu dilihat berjaya melawan pihak komunis. Antaranya, pada 19 Mei 1952, sekumpulan 30 orang komunis menyerang rumah kongsi pelombong di Tapah dan berjaya menawan pos kawalan Polis Bantuan. Namun begitu, pasukan Polis Bantuan di pos kawalan berdekatan membalas serangan komunis dan akhirnya berjaya menghalau mereka. ${ }^{58}$

Konstabel Khas diwujudkan untuk melindungi estet, lombong dan kilang di kawasan luar bandar. Setiap estet, lombong dan kilang mempunyai kekuatan Konstabel Khas yang berbeza mengikut permintaan pengurus. Di kawasan Sungai Siput sahaja, seramai 275 orang Konstabel Khas ditempatkan di 10 buah estet kepunyaan peladang Eropah pada tahun $1952^{59}$ seperti mana dalam Jadual 3. Penugasan Konstabel Khas dipantau oleh polis tetap. ${ }^{60}$ Tugas mengiringi dan menjaga keselamatan pengurus estet serta lombong juga merupakan sebahagian daripada tanggungjawab Konstabel Khas. Selain itu, Konstabel Khas juga menjalankan tugas mengawal sasaran penting seperti loji hidroeletrik $^{61}$ dan membuat pemeriksaan kawalan makanan. Konstabel Khas dengan dilengkapi senjata api turut mengiringi kumpulan penoreh getah untuk ke ladang. Setiap kenderaan atau individu yang masuk atau keluar daripada estet perlu diperiksa oleh Konstabel Khas. Konstabel Khas turut menjalankan tugas rondaan di kawasan ladang getah. ${ }^{62}$ Adakalanya rondaan pasukan ini terserempak dengan komunis seperti insiden pada 28 September 1948 di mana Konstabel Khas menahan dan menyoal siasat seorang lelaki Cina yang menunggang basikal di Bedford Estate, Slim River. Namun, lelaki Cina itu bertindak meninggalkan basikalnya dan melarikan diri sejauh 300 ela sebelum ditembak mati oleh Konstabel Khas. 
Sejarah: Journal of History Department, University of Malaya; No. 29 (1) 2020: 158-177; ISSN 1985-0611.

Jadual 2: Statistik Peladang Eropah Terbunuh di Perak pada Zaman Darurat

\begin{tabular}{|l|l|l|l|l|l|l|l|l|l|l|}
\hline Kawasan & 1948 & 1949 & 1950 & 1951 & 1952 & 1953 & 1954 & 1955 & 1956 & Jumlah \\
\hline Sungai Siput & 3 & - & 1 & 1 & 1 & - & 2 & - & 1 & 9 \\
\hline Tapah & - & - & 2 & - & - & - & - & - & - & 2 \\
\hline Teluk Intan & - & - & - & - & 2 & - & - & - & - & 2 \\
\hline Sungkai & - & - & 1 & - & - & - & - & - & - & 1 \\
\hline $\begin{array}{l}\text { Tanjung } \\
\text { Malim }\end{array}$ & - & - & - & 1 & - & - & - & - & - & 1 \\
\hline Slim River & - & - & - & 1 & - & - & - & - & - & 1 \\
\hline Batu Gajah & - & - & - & 1 & 1 & - & - & - & - & 2 \\
\hline Bidor & - & - & - & 2 & - & - & - & - & - & 2 \\
\hline Ipoh & - & - & 1 & - & - & - & - & - & - & 1 \\
\hline Bruas & - & 1 & - & - & - & - & - & - & - & 1 \\
\hline Jumlah & 3 & 1 & 5 & 6 & 4 & 0 & 2 & 0 & 1 & 22 \\
\hline
\end{tabular}

Sumber: R. Thambipillay, Little God's Acre 1948-1960, Ipoh: Perak Planter's Association Publication, 1998, hlm. 199.

Jadual 3: Kekuatan Konstabel Khas di Estet di Sungai Siput pada tahun 1952

\begin{tabular}{|c|c|c|}
\hline Nama Pengurus & Estet & Jumlah Konstable Khas \\
\hline T. B. Spones & Sungai Krudda & 32 \\
\hline H. Claxton & Sungai Reyla & 23 \\
\hline M. H Jerram & Elphil \& Plang & 39 \\
\hline W. H Davis & Phin Soon & 31 \\
\hline P. M Geering & Kemari & 23 \\
\hline K. B Mellison & Headwood & 19 \\
\hline St. Cl. Moferd & Dovenby & 22 \\
\hline C. T Ross & Kamuning & 39 \\
\hline W. G Rollo & Changkat Salak & 33 \\
\hline A. J Warrik & Jalong Tinggi & 14 \\
\hline Jumlah & - & 275 \\
\hline
\end{tabular}

Sumber: Jayakumary Marimuthu, "Zaman Darurat, 1948-1960: Kajian Keadaan

Sosioekonomi Di Sungai Siput (U)", Malaysia dari segi Malaysia, Bil. 40, 2012, hlm. 124. 
Pasukan Flying Squad turut ditugaskan untuk menjaga keselamatan di kawasan estet dan lombong. Pada 16 Ogos 1948, sepasukan Flying Squad bergegas ke kawasan lombong timah di Kinta untuk membuat pemeriksaan dan menemani pekerja lombong sehingga tengah malam selepas menerima laporan berhubung pergerakan 30 orang komunis di kawasan itu. ${ }^{63}$ Sementara itu, pada 23 Ogos 1948, Flying Squad membuat serbuan di sebuah lombong timah berdekatan Chemor. Dalam serbuan tersebut, Konstabel Khas berjaya mencederakan seramai tiga orang komunis dan turut menangkap seorang komunis. ${ }^{64}$ Dalam insiden lain, pasukan polis berjaya menangkap seorang ejen komunis di Sungkai Estate pada 24 Januari 1949. Komunis itu dikenal pasti terlibat secara aktif dalam PKM. ${ }^{65}$ Pada 25 Mei 1951 pula, seorang pengurus ladang dan pelawat berjaya menyelamatkan diri ketika diserang hendap oleh komunis. Pasukan Polis Hutan yang mengiring mereka bertindak membalas tembakan komunis sehingga komunis melarikan diri dan seorang komunis dicederakan. ${ }^{66}$ Selain itu, rondaan pasukan polis di kawasan estet dan lombong turut menjumpai komunis yang ingin menyerah diri. Sebagai contoh, seorang komunis bersama isterinya dan dua orang anaknya menyerah diri kepada pasukan rondaan Kompeni Hutan di Kati Estate, Kuala Kangsar pada 30 Oktober 1952. ${ }^{67}$ Dalam insiden lain pada 23 Mac 1952, Kompeni Hutan berjaya menyerang hendap dan membunuh dua orang komunis berdekatan jalan estet di Tapah selepas menerima maklumat yang disampaikan oleh orang awam. ${ }^{68}$ Dalam kejadian lain, pada 1 Ogos 1952, Skuad Hutan yang memantau di rumah kongsi di kawasan lombong di utara Sungai Siput berjaya membunuh seorang komunis, mencederakan seorang lagi dan memberkas tiga orang komunis yang sedang mengambil bekalan yang disembunyikan berdekatan rumah kongsi berkenaan. ${ }^{69}$ Kehadiran pasukan polis dilihat berkesan melindungi kakitangan serta aset di estet dan lombong daripada seranngan komunis.

\section{Kawalan Keselamatan Terhadap Kemudahan Pengangkutan Kereta Api}

Pihak komunis turut melancarkan serangan ke atas kereta api serta laluan kereta api di Perak dengan niat untuk menimbulkan suasana tidak tenteram dan menyusahkan pergerakan seharian penduduk yang menggunakan perkhidmatan ini. Tindakan komunis ini boleh menyebabkan penduduk kehilangan keyakinan kepada kerajaan dalam melindungi keselamatan nyawa dan harta mereka. Sebaliknya kesempatan ini boleh digunakan oleh komunis bagi memperoleh sokongan penduduk. Antara contoh kegiatan sabotaj komunis berlaku pada 24 Oktober 1948, komunis cuba membakar stesen kereta api di Chemor. Namun, tindakan jahat komunis berjaya dikesan sebelum mereka sempat menyalakan api. ${ }^{70}$ Di Taiping, komunis melakukan cubaan untuk mensabotaj landasan kereta api berdekatan Pondok Tanjong dengan meletakkan dua tiang besi telefon di laluan kereta api. Namun, percubaan sabotaj komunis tidak berjaya kerana kereta api dapat merempuh tiang besi telefon berkenaan dan melalui laluan itu tanpa sebarang kerosakan. ${ }^{71}$ Justeru, kehadiran pasukan polis dalam menjaga kereta api dan penumpangnya adalah penting bagi mengelak stesen dan landasan kereta api terus disabotaj oleh komunis. Komunis mentaksirkan kereta api sebagai sasaran mudah bagi mereka. Sebahagian besar serangan ke atas stesen, landasan dan kereta api berlaku di kemuncak zaman darurat, iaitu antara tahun 1949 dan 1951. Namun, serangan komunis ke atas sistem kereta api berkurangan selepas tahun $1952^{72}$ kerana kawalan ketat oleh pasukan keselamatan.

Dalam menjalankan tugas, Home Guard ditempatkan di menara kawalan untuk melindungi jambatan landasan kereta api daripada sabotaj komunis. ${ }^{73}$ Sementara itu, kawalan dan rondaan pasukan polis di laluan kereta api juga berjaya menjumpai senjata api yang digunakan oleh komunis. Antaranya, pihak polis berjaya menjumpai selaras senjata api jenis Sten Gun bersama 20 rantai peluru berdekatan laluan kereta api di 
Stesen Tanjung Rambutan pada 24 Januari 1949. ${ }^{74}$ Pada 3 September 1952, kereta api yang membawa surat tergelincir daripada landasan di kawasan Slim River. Dalam kejadian ini, seorang koperal dari No. 5 Police Jungle Company tercedera di bahagian lengan dan pekerja kereta api turut luka akibat terkena pecahan kaca. ${ }^{75}$ Memandangkan itu, kerajaan mengambil langkah lain untuk mengurangkan sabotaj dan kemalangan kereta api dengan memperkenalkan ciptaan inovasi yang dikenali sebagai Armoured Wickham Trolley. Ianya dicipta khas sebagai pemandu kereta api untuk mengatasi halangan di landasan. Armoured Wickham Trolley ini mula diperkenalkan pada tahun 1951 dan reka bentuknya diubah suai mengikut permintaan pasukan polis dan pasukan tentera. Pada tahun 1953, sebanyak 42 buah Armoured Wickham Trolley dibawa masuk dalam perkhidmatan, namun serangan komunis ke atas kereta api pada ketika itu sudah berkurangan. ${ }^{76}$ Hal ini membuktikan usaha pasukan polis untuk mempertingkatkan kawalan keselamatan terhadap kemudahan kereta api dilihat berkesan untuk menangani ancaman komunis.

\section{Operasi Keselamatan di Kawasan Pedalaman dan Hutan}

Kumpulan komunis bersembunyi di kawasan pedalaman dan hutan bagi mengelakkan daripada diserang dengan mudah oleh pasukan polis. Ekoran daripada itu, pasukan polis khususnya Skuad Hutan, Kompeni Hutan, Pasukan Polis Hutan dan Senoi Praaq digerakkan merentasi hutan tebal untuk mengesan dan menghapuskan komunis yang bersembunyi di kawasan pedalaman dan hutan di Perak. Hal ini kerana unit-unit pasukan polis tersebut banyak menjalankan tugas rondaan di kawasan pedalaman dan hutan. Pasukan Kompeni Hutan mempunyai khemah dan peralatan yang lebih lengkap, anggota yang terlatih serta lebih ramai untuk menjalankan operasi di dalam kawasan pedalaman hutan bagi tempoh lama berbanding Skuad Hutan yang membuat rondaan tempoh pendek di kawasan pedalaman. ${ }^{77}$ Manakala, Senoi Praaq mempunyai kemahiran dalam ilmu ketenteraan, cara menggunakan senjata api, taktik peperangan dalam hutan dan membuat tinjauan untuk memburu komunis kerana diberi latihan bersama-sama dengan Pasukan 22nd Special Air Service Regiment (SAS). ${ }^{78}$ Tidak ketinggalan, Cawangan Khas turut melancarkan operasi-operasi di kawasan pedalaman Perak untuk melemahkan gerakan komunis berdasarkan risikan maklumat.

Pasukan Polis Hutan ditugaskan untuk menjaga pertahanan kubu, beroperasi di pedalaman hutan, menjaga sempadan Thailand dan kejadian rusuhan. ${ }^{79}$ Pasukan Polis Hutan giat membuat rondaan dan memusnahkan kem-kem komunis yang tersembunyi jauh di kawasan pedalaman dan hutan. Antaranya, pada 11 Ogos 1948, lebih kurang 20 orang komunis melepaskan tembakan ke atas pasukan polis di Tapah. Pasukan polis membalas tembakan dan berjaya membunuh dua orang komunis, iaitu seorang lelaki dan seorang wanita. Anggota komunis lain meninggalkan kem mereka dan melarikan diri ke dalam hutan. Pihak polis bertindak membakar kem komunis yang mempunyai beberapa helai pakaian seragam komunis. ${ }^{80}$ Dalam kejadian pada 8 September 1949 pula, dua orang Skuad Hutan menemui dua buah kem komunis di kawasan pedalaman Kampar dan berjaya membuat tangkapan ke atas dua orang komunis yang cuba melarikan diri dengan merangkak di dalam kawasan lalang. ${ }^{81}$

Dalam tempoh Januari hingga November 1949, sebanyak 199 buah kem komunis berjaya ditemui dan dimusnahkan oleh pasukan keselamatan di Perak daripada jumlah 1,108 buah kem komunis yang ditemui di seluruh Tanah Melayu. ${ }^{82}$ Setiap kem komunis yang ditemui akan diperiksa terlebih dahulu sebelum dibakar agar pihak komunis tidak dapat untuk terus tinggal di kem tersebut. Pasukan polis membawa balik senjata api, dokumen komunis dan makanan simpanan yang ditemui di dalam kem komunis. ${ }^{83}$ Skuad Hutan di Tronoh berjaya membunuh seorang dan mencederakan beberapa orang komunis yang melarikan diri pada 2 Oktober 1949. Pasukan itu 
memusnahkan sebuah kem yang memuatkan 20 orang komunis dan menjumpai dua butir bom tangan serta pelbagai jenis peluru. ${ }^{84}$ Sementara itu, sebanyak 475 laras senjata api milik komunis dijumpai di Perak daripada jumlah keseluruhan sebanyak 2,738 laras senjata api yang dijumpai di seluruh Tanah Melayu di antara Januari hingga Oktober $1949 .{ }^{85}$ Dalam tempoh yang sama, sebanyak 441,713 butir peluru senjata api ringan ditemui di seluruh Tanah Melayu dan di Perak sahaja berjaya menemui sebanyak 28,622 butir peluru. ${ }^{86}$ Kejayaan pihak polis menjumpai kem dan senjata api dapat menyekat gerakan komunis. Ini kerana keadaan kekurangan senjata api dapat memaksa pihak komunis untuk cuba mengelak daripada bertempur dengan pasukan polis tanpa perancangan rapi seperti melancarkan serangan hendap. Seramai 114 orang komunis berjaya dibunuh di Perak daripada jumlah keseluruhan 558 orang komunis yang dibunuh di seluruh Tanah Melayu dalam tempoh Januari hingga November $1949 .{ }^{87}$

Pasukan Polis Hutan juga ditugaskan untuk mengawal di kubu hutan yang dibina untuk melindungi keselamatan Orang Asli daripada gangguan komunis. Sehingga tahun 1953, seramai 29,320 Orang Asli yang masih terdedah kepada pengaruh komunis di Tanah Melayu dan Perak sahaja mencatatkan seramai 11,500 orang ${ }^{88}$. Di kawasan pedalaman dan hutan, komunis mendapatkan makanan dan maklumat berkenaan pergerakan pasukan keselamatan daripada Orang Asli. Justeru, sebanyak 11 buah kubu hutan dibina di Tanah Melayu sehingga tahun 1957 dan dikendalikan oleh Pasukan Polis Hutan. Pusat perubatan dan perdagangan juga diwujudkan di setiap kubu. ${ }^{89} \mathrm{Kubu}$ yang dibina itu adalah berperanan memberi pelindungan kepada Orang Asli serta mengelakkan pihak komunis daripada mendekati Orang Asli untuk mendapatkan bekalan makanan dan maklumat. ${ }^{90}$ Namun, Fort Slim di Perak dan Fort Langkap di Negeri Sembilan ditutup apabila keadaan darurat semakin pulih pada Mac 1960. Sementara itu, kubu lain masih lagi beroperasi untuk tujuan pentadbiran. ${ }^{91}$

Selain menjalankan tugas perisikan di kawasan penempatan penduduk, Cawangan Khas turut terlibat dalam operasi untuk membanteras komunis di kawasan pedalaman dan hutan. Antara operasi yang dilancarkan oleh Cawangan Khas adalah seperti Operation Bintang, Operation Ginger dan Operation Bamboo. Cawangan Khas melancarkan Operation Bintang pada 16 Januari 1958 di selatan Perak. Kekuatan komunis adalah seramai 60 orang apabila operasi ini dilancarkan. ${ }^{92}$ Operation Bintang melibatkan kawasan selatan Perak meliputi sebahagian besar daerah Kinta termasuk Batu Gajah, Tronoh dan Parit. ${ }^{93}$ Operation Bintang berakhir pada pertengahan September 1958 dengan pencapaian kejayaan 100 peratus. Kesemua 60 orang komunis berjaya ditumpaskan dalam operasi ini iaitu 23 orang komunis dibunuh, 32 orang menyerah diri, tiga orang ditangkap dan dua lagi dilaporkan hilang. ${ }^{94}$

Di samping itu, Cawangan Khas juga berjaya menumpaskan seramai 162 orang komunis dalam Operation Ginger dalam tempoh Februari 1958 hingga April 1959. ${ }^{95}$ Operation Ginger menyasarkan kumpulan komunis yang dijangkakan seramai 200 orang di kawasan tengah Perak yang dipercayai memperoleh bantuan makanan yang mencukupi. ${ }^{96}$ Operasi ini menyasarkan untuk menghapuskan pengagihan bekalan makanan dan ubat-ubatan kepada komunis oleh penduduk yang tinggal di pinggir hutan yang bersimpati dengan mereka. Langkah pertama yang dilaksanakan ketika Operation Ginger adalah mengawal jumlah makanan yang ada. Seterusnya, memperketatkan pengendalian pengedaran makanan di kawasan operasi. ${ }^{97}$ Antara kawasan yang tersenarai dalam Operation Ginger adalah di utara Ipoh yang meliputi daerah Sungai Siput, Kuala Kangsar dan Kinta. ${ }^{98}$

Manakala, Operation Bamboo dilancarkan oleh Cawangan Khas di kawasan Perak dan sempadan Kelantan pada 15 Oktober 1959. ${ }^{99}$ Operasi ini bertujuan untuk menghapuskan lebih kurang 40 orang komunis dan memenangi hati lebih kurang 200 
Orang Asli yang diperalatkan oleh komunis sebagai pelindung dan pembekal sumber bekalan kepada mereka. ${ }^{100}$ Operasi kawasan meliputi kawasan hutan Ulu Perak di utara Sungai Siput dan kawasan hutan di barat Kelantan. Dalam operasi ini, Cawangan Khas dan Senoi Praaq saling bekerjasama dalam membina rangkaian perisikan bagi operasi ini ${ }^{101}$ di samping memutuskan perhubungan Orang Asli dengan komunis. Senoi Praaq ditugaskan untuk menghapuskan pengaruh komunis dengan memujuk Orang Asli agar memihak kepada kerajaan dan bukannya pihak komunis. Hal ini kerana kawasan itu dikuasai oleh komunis sejak zaman pendudukan Jepun pada tahun 1942. Pihak komunis mendapat perlindungan, makanan dan maklumat daripada Orang Asli di kawasan berkenaan. ${ }^{102}$

Walaupun pihak komunis cuba menyembunyikan diri di kawasan pedalaman dan hutan tebal di Perak, namun tindakan mereka itu adalah sia-sia. Pasukan polis ditugaskan untuk membuat rondaan dan operasi untuk mengesan dan menjejaki komunis di setiap kawasan pedalaman dan hutan di Perak. Usaha pemantauan dan rondaan pasukan polis berjaya menjumpai kem-kem komunis, bekalan makanan, senjata api dan dokumen komunis. Pergerakan pasukan polis di kawasan pedalaman dan hutan memaksa komunis tidak dapat berehat di sesuatu lokasi untuk tempoh yang lama bagi mengelakkan daripada bertempur dengan pasukan polis. Usaha pasukan polis juga berjaya menghapuskan tempat persembunyian komunis dan mempengaruhi Orang Asli untuk memberi kerjasama kepada kerajaan dalam usaha membanteras komunis di Perak.

\section{Kesimpulan}

Sepanjang zaman darurat, komunis melancarkan serangan ke atas orang awam, bangunan dan kemudahan awam sehingga menimbulkan kegusaran penduduk di Tanah Melayu termasuk Perak. Bagi menghadapi bilangan komunis yang ramai beroperasi di dalam hutan dan penyokong komunis di serata Tanah Melayu termasuk Perak, kerajaan mengambil langkah dengan memperbesarkan kekuatan pasukan polis dengan penubuhan pelbagai cawangan dan unit pasukan polis pada awal zaman darurat. Hal ini kerana kekuatan komunis (12,500 orang) adalah melebihi kekuatan pasukan polis (9,000 orang) pada awal zaman darurat. Justeru, langkah terbaik bagi melawan pihak komunis adalah menggandakan kekuatan pasukan polis yang sedia ada pada ketika itu. Susulan daripada itu, antara pasukan yang diwujudkan pada zaman darurat adalah Konstabel Khas, Polis Bantuan, Home Guard, Cawangan Khas, Polis Wanita, Senoi Praaq, Flying Squad, Skuad Hutan, Kompeni Hutan dan Pasukan Polis Hutan.

Unit dan cawangan yang diwujudkan oleh pasukan polis ditempatkan di kawasan penempatan penduduk dan sekitarnya agar menjaga keselamatan penduduk di Perak daripada ancaman komunis. Langkah pasukan polis membuat rondaan dan pemeriksaan serta kawalan makanan pula dapat mengurangkan serangan komunis ke atas penduduk. Langkah ini juga dapat melemahkan penyebaran pengaruh komunis dalam kalangan penduduk di Perak. Selain itu, pihak polis juga ditugaskan untuk menjaga keselamatan kakitangan di estet dan lombong serta menjamin kelancaran perkhidmatan kereta api di Perak. Pada masa yang sama, rondaan dan operasi yang dijalankan oleh pasukan keselamatan di kawasan pedalaman serta hutan bagi menghapuskan komunis secara menyeluruh. Tindakan pasukan polis bukan sahaja berjaya menjamin keselamatan penduduk, tetapi juga berjaya menghapuskan ancaman komunis di Perak pada zaman darurat. 
Nota

* Cheang Fook Hong merupakan lulusan Ijazah Sarjana dari Jabatan Sejarah, Universiti Malaya (UM). Kini beliau berkhidmat sebagai Pegawai Polis di Ibu Pejabat Polis Diraja Malaysia.

** Dr. Ho Hui Ling merupakan Pensyarah Kanan di Jabatan Sejarah, Fakulti Sastera dan Sains Sosial, Universiti Malaya, Kuala Lumpur. Bidang pengkhususan beliau ialah Sejarah Malaysia. Beliau telah menjalankan banyak kajian berkaitan sejarah zaman darurat dan gerakan komunis, hubungan etnik, perkembangan masyarakt majmuk, pembangunan sosioekonomi serta pelbagai aspek sejarah Sarawak dan Sabah. Hasil kajiannya telah diterbitkan dalam bentuk buku, bab dalam buku dan artikel jurnal serta dimuatkan dalam laporan penyelidikan dan kertas persidangan.

${ }^{1}$ WO 106/5990, Review Of The Emergency In Malaya From June 1948 To August 1957, Emergency Measures And Anti-Terrorist Operations, hlm. 12.

2 Mohd Azzam Hanif Ghows, The Malayan Emergency Revisited 1948-1960, Kuala Lumpur: AMR Holding Sdn Bhd, 2007, hlm. 48.

${ }^{3}$ Yuen Yuet Leng, Operation Ginger, Kuala Lumpur: Vinpress Sdn. Bhd., 1998

${ }^{4}$ Mohd Razali bin Ya'acob@Jusoh, 'Home Guard di Perak, 1948-1960', Disertasi Sarjana, Jabatan Sejarah, Fakulti Sastera dan Sains Sosial, Universiti Malaya, Kuala Lumpur, 2016.

5 Robert Jackson, The Malayan Emergency: The Commonwealth's Wars 1948-1966, London: Routledge, 1991, hlm. 14.

${ }^{6}$ Temubual dengan Datuk Dr. Leong Chee Woh, bekas Pegawai Cawangan Khas, di rumahnya di Seri Kembangan, Selangor pada 7 April 2019.

${ }^{7}$ Richard Clutterbuck, Riot And Revolution In Singapore And Malaya, 1945-1963, London: Faber And Faber Limited, 1973, hlm. 179.

${ }^{8}$ A452/1968/4248, Review Of The Emergency In Malaya From June 1948 To August 1957 By The Director Of Operations Malaya, 1957-1967, hlm. 20.

${ }^{9}$ CO 1022/151/75/395/01, Communism: Malaya Rehabilitation Of Detainees, hlm. 17.

10 Ray Nyce, Chinese New Villages In Malaya: A Community Study, Singapura: Malaysian Sociological Research Institute, 1973, hlm. 4a.

11 John Kerry King, “ Malaya’s Resettlement Problem”, Far Eastern Survey, Vol. 23, No.3, 1954, hlm. 36.

${ }^{12}$ Mohd Azzam Hanif Ghows, The Malayan Emergency Revisited 1948-1960, hlm. 96.

${ }^{13}$ Ibid., hlm. 204.

${ }^{14}$ The Straits Times, 14 Ogos 1948, hlm. 7.

${ }^{15}$ Indian Daily Mail, 19 April 1952, hlm. 1; The Straits Times, 19 April 1952, hlm. 1.

${ }^{16}$ Singapore Standard, 14 Mei 1952, hlm. 1.

${ }^{17}$ The Singapore Free Press, 10 April 1952, hlm. 5.

${ }^{18}$ CO 1022/29/10/72/01 The Resettlement Of Squatters In Malaya, hlm. 75.

${ }^{19}$ John Kerry King, “ Malaya’s Resettlement Problem”, hlm. 36.

${ }^{20}$ Mohd Azzam Hanif Ghows, The Malayan Emergency Revisited 1948-1960, hlm. 207.

${ }^{21}$ Ibid., hlm. 82.

${ }^{22}$ Temubual dengan Datuk Dr. Leong Chee Woh, bekas Pegawai Cawangan Khas, di rumahnya di Seri Kembangan, Selangor pada 7 April 2019.

${ }^{23}$ The Straits Times, 28 Julai 1950, hlm. 5.

${ }^{24}$ Malaya Tribune, 25 Februari 1949, hlm. 3.

${ }^{25}$ Malaya Tribune, 29 Mac 1949, hlm. 2.

${ }^{26}$ The Straits Times, 16 April 1949, hlm. 1.

27 The Straits Times, 27 Julai 1949, hlm. 5.

${ }^{28}$ File Special Branch Perak Police Contingent Headquarters, Federation Of Malaya Police Force, 1950.

${ }^{29}$ Mohd Azzam Hanif Ghows, The Malayan Emergency Revisited 1948-1960, hlm. 106.

${ }^{30}$ The Straits Times, 21 Jun 1951, hlm. 7.

31 Temubual dengan Datuk Dr. Leong Chee Woh, bekas Pegawai Cawangan Khas, di rumahnya di Seri Kembangan, Selangor pada 7 April 2019.

${ }^{32}$ Yuen Yuet Leng, Operation Ginger, hlm. 41.

${ }^{33}$ The Straits Times, 31 Disember 1953, hlm. 7.

${ }^{34}$ Mohd Azzam Hanif Ghows, The Malayan Emergency Revisited 1948-1960, hlm. 95.

${ }^{35}$ Yuen Yuet Leng, Operation Ginger, hlm. 41.

${ }^{36}$ Ibid., hlm. 39.

${ }^{37}$ Berita Harian, 3 Disember 1958, hlm. 4. 
${ }^{38}$ Yuen Yuet Leng, Operation Ginger, hlm. 67.

${ }^{39}$ The Straits Times, 9 Julai 1959, hlm. 5.

${ }^{40}$ The Straits Times, 12 Disember 1960, hlm. 5.

${ }^{41}$ Berita Harian, 9 Julai 1959, hlm. 1.

${ }^{42}$ The Straits Times, 9 Januari 1959, hlm. 1.

${ }^{43}$ The Straits Times, 9 Disember 1959, hlm. 12.

${ }^{44}$ Berita Harian, 13 Mac 1959, hlm. 6.

${ }^{45}$ The Straits Times, 11 Januari 1960, hlm. 6.

46 A452/1968/4248, Review Of The Emergency In Malaya From June 1948 To August 1957 By The Director Of Operations Malaya, 1957-1967, hlm. 12.

${ }^{47}$ Mohd Azzam Hanif Ghows, The Malayan Emergency Revisited 1948-1960, hlm. 78.

48 A452/1968/4248, Review Of The Emergency In Malaya From June 1948 To August 1957 By The Director Of Operations Malaya, 1957-1967, hlm. 22.

${ }^{49}$ CO 717/169/52849/8/1, Law And Order Military Situation FARELF Sitreps, Cipher Telegram, 1 November 1948, hlm. 3.

${ }^{50}$ Singapore Standard, 15 Julai 1950, hlm. 4.

${ }^{51}$ The Straits Times, 16 September 1953, hlm. 1.

52 The Straits Times, 26 Oktober 1954, hlm. 10.

${ }^{53}$ Mohd Azzam Hanif Ghows, The Malayan Emergency Revisited 1948-1960, hlm. 68.

54 R. Thambipillay, Little God's Arce 1948-1960, Ipoh: Perak Planter's Association Publication, 1998, hlm. 199.

55 Ibid., hlm. 205.

${ }^{56}$ A452/1968/4248, Review Of The Emergency In Malaya From June 1948 To August 1957 By The Director Of Operations Malaya, 1957-1967, hlm. 22.

${ }^{57}$ Mohd Azzam Hanif Ghows, The Malayan Emergency Revisited 1948-1960, hlm. 215.

${ }^{58}$ The Straits Times, 20 Mei 1952, hlm. 7.

59 Jayakumary Marimuthu, "Zaman Darurat, 1948-1960: Kajian Keadaan Sosioekonomi Di Sungai Siput (U)”, Malaysia dari segi Malaysia, Bil. 40, 2012, hlm. 124.

${ }^{60}$ A452/1968/4248, Review Of The Emergency In Malaya From June 1948 To August 1957 By The Director Of Operations Malaya, 1957-1967, hlm. 25.

61 Temubual dengan Datuk Dr. Leong Chee Woh, bekas Pegawai Cawangan Khas, di rumahnya di Seri Kembangan, Selangor pada 26 Mei 2019.

${ }^{62}$ Mohd Azzam Hanif Ghows, The Malayan Emergency Revisited 1948-1960, hlm. 195.

${ }^{63}$ Morning Tribune, 19 Ogos 1948, hlm. 1; Malaya Tribune, 19 Ogos 1948, hlm. 6.

${ }^{64}$ Morning Tribune, 24 Ogos 1948, hlm. 1

${ }^{65}$ Morning Tribune, 25 Januari 1949, hlm. 2.

${ }^{66}$ The Straits Times, 26 Mei 1951, hlm. 7.

${ }^{67}$ The Straits TImes, 31 Oktober 1952, hlm. 1.

${ }^{68}$ The Straits TImes, 24 Mac 1952, hlm. 1.

69 The Straits TImes, 2 Ogos 1952, hlm. 1.

${ }^{70}$ CO 717/169/52849/8/1, Law And Order Military Situation FARELF Sitreps, Cipher Telegram, 1 November 1948, hlm. 3.

${ }^{71}$ The Straits Times, 14 Mac 1949, hlm. 5.

${ }^{72}$ Mohd Azzam Hanif Ghows, The Malayan Emergency Revisited 1948-1960, hlm. 72.

${ }^{73}$ Ibid., hlm. 74.

${ }^{74}$ Morning Tribune, 25 Januari 1949, hlm. 2.

75 The Straits Times, 4 September 1952, hlm. 1.

${ }^{76}$ Mohd Azzam Hanif Ghows, The Malayan Emergency Revisited 1948-1960, hlm. 75.

77 R. Thambipillay, The Malayan Police Force In The Emergency, 1948-1960, Perak: Goodturn Hoover Trading, 2003, hlm. 11.

78 Pasukan Khas bagi Tentera British yang ditubuhkan pada tahun 1941 dan dihantar untuk berkhidmat di Persekutuan Tanah Melayu pada tahun 1950. Pada awalnya, pasukan ini dikenali sebagai The Malayan Scouts.

${ }^{79}$ A452/1968/4248, Review Of The Emergency In Malaya From June 1948 To August 1957 By The Director Of Operations Malaya, 1957-1967, hlm. 23.

${ }^{80}$ The Straits Times, 11 Ogos 1948, hlm. 1.

${ }^{81}$ The Straits Times, 9 September 1949, hlm. 3.

${ }^{82}$ CO 825/74/3/55404/3, Monthly Political Reports From Federation Of Malaya, Appendix 'E', hlm. 31.

${ }^{83}$ Temubual dengan Datuk Dr. Leong Chee Woh, bekas Pegawai Cawangan Khas, di rumahnya di Seri Kembangan, Selangor pada 26 Mei 2019. 
84 The Singapore Free Press, 3 Oktober 1949, hlm. 1.

${ }^{85}$ CO 825/74/3/55404/3, Monthly Political Reports From Federation Of Malaya, Appendix 'D', hlm. 30 .

${ }^{86}$ CO 825/74/3/55404/3, Monthly Political Reports From Federation Of Malaya, Appendix 'B', hlm. 28.

${ }^{87}$ CO 825/74/3/55404/3, Monthly Political Reports From Federation Of Malaya, Appendix 'I', hlm. 34.

${ }^{88}$ Ho Hui Ling, Pembanterasan Komunis Di Tanah Melayu, Kuala Lumpur: Penerbit Universiti Malaya, 2010, hlm. 138.

${ }^{89}$ A452/1968/4248, Review Of The Emergency In Malaya From June 1948 To August 1957 By The Director Of Operations Malaya, 1957-1967, hlm. 22.

90 Temubual dengan Datuk Dr. Leong Chee Woh, bekas Pegawai Cawangan Khas di rumahnya di Seri Kembangan, Selangor pada 26 Mei 2019.

${ }^{91}$ Berita Harian, 30 Mac 1960, hlm. 5; The Straits Times, 30 Mac 1960, hlm. 5.

92 The Straits Times, 27 September 1958, hlm. 5.

${ }^{93}$ The Straits Times, 17 Januari 1958, hlm. 1.

94 The Stratis Times, 30 Julai 1960, hlm. 2.

95 Leon Comber, Malaya's Secret Police 1945-1960: The Role Of The Special Branch In The Malayan Emergency, Singapore: Institute of South Asian Studies, 2008, hlm. 280.

96 The Straits Times, 10 Jun 1958, hlm. 8.

${ }^{97}$ Peter Dennis dan Jeffrey Grey, Emergency and Confrontation: Australian Military Operations In Malaya and Borneo, 1950-1966, New South Wales: Allen \& Unwin In Association With The Australian War Memorial, 1996, hlm. 136.

${ }^{98}$ The Straits Times, 17 Januari 1958, hlm. 1.

${ }^{99}$ The Stratis Times, 29 April 1960, hlm. 5.

100 The Stratis Times, 11 Januari 1960, hlm. 6.

${ }^{101}$ Shamsul Afkar bin Abd Rahman, 'History Of Special Operations Forces In Malaysia', Master Of Science In Defense Analysis, Naval Postgraduate School, California, 2013, hlm. 40.

102 Berita Harian, 20 Julai 1960, hlm. 2.

\section{Bibiografi}

\section{Sumber Primer}

\section{Colonial Office Records}

Communism: Malaya Rehabilitation Of Detainees, CO 1022/151/75/395/01.

The Resettlement Of Squatters In Malaya, CO 1022/29/10/72/01.

Law And Order Military Situation FARELF Sitreps, Cipher Telegram, 1 November 1948, CO 717/169/52849/8/1.

Monthly Political Reports From Federation Of Malaya, CO 825/74/3/55404/3.

\section{War Office Records}

Review Of The Emergency In Malaya From June 1948 To August 1957, Emergency Measures And Anti-Terrorist Operations, WO 106/5990.

\section{National Archives Of Australia Records}

Review Of The Emergency In Malaya From June 1948 To August 1957 By The Director Of Operations Malaya, 1957-1967, A452/1968/4248. 
Fail Koleksi Cawangan Khas, Ibu Pejabat Polis Diraja Malaysia, Bukit Aman

File Special Branch Perak Police Contingent Headquarters, Federation Of Malaya Police Force, 1950.

\author{
Akhbar \\ Berita Harian, 13 Mac 1959. \\ Berita Harian, 20 Julai 1960. \\ Berita Harian, 3 Disember 1958. \\ Berita Harian, 30 Mac 1960 \\ Berita Harian, 9 Julai 1959. \\ Indian Daily Mail, 19 April 1952. \\ Malaya Tribune, 19 Ogos 1948. \\ Malaya Tribune, 25 Februari 1949. \\ Malaya Tribune, 29 Mac 1949. \\ Morning Tribune, 19 Ogos 1948. \\ Morning Tribune, 24 Ogos 1948. \\ Morning Tribune, 25 Januari 1949. \\ Singapore Standard, 14 Mei 1952. \\ Singapore Standard, 15 Julai 1950. \\ The Singapore Free Press, 10 April 1952. \\ The Singapore Free Press, 3 Oktober 1949. \\ The Straits Times, 10 Jun 1958. \\ The Straits Times, 11 Januari 1960. \\ The Straits Times, 11 Ogos 1948. \\ The Straits Times, 12 Disember 1960. \\ The Straits Times, 14 Mac 1949. \\ The Straits Times, 14 Ogos 1948. \\ The Straits Times, 16 April 1949. \\ The Straits Times, 16 September 1953. \\ The Straits Times, 17 Januari 1958. \\ The Straits Times, 19 April 1952. \\ The Straits TImes, 2 Ogos 1952. \\ The Straits Times, 20 Mei 1952. \\ The Straits Times, 21 Jun 1951. \\ The Straits TImes, 24 Mac 1952. \\ The Straits Times, 26 Mei 1951. \\ The Straits Times, 26 Oktober 1954. \\ The Straits Times, 27 Julai 1949. \\ The Straits Times, 27 September 1958. \\ The Straits Times, 28 Julai 1950. \\ The Straits Times, 30 Mac 1960. \\ The Straits Times, 31 Disember 1953. \\ The Straits TImes, 31 Oktober 1952. \\ The Straits Times, 4 September 1952. \\ The Straits Times, 9 Disember 1959. \\ The Straits Times, 9 Januari 1959. \\ The Straits Times, 9 Julai 1959. \\ The Straits Times, 9 September 1949. \\ The Stratis Times, 11 Januari 1960.
}


The Stratis Times, 29 April 1960.

The Stratis Times, 30 Julai 1960.

\section{Sumber Sekunder}

\section{Buku}

Clutterbuck, Richard, Riot And Revolution In Singapore And Malaya, 1945-1963, London: Faber And Faber Limited, 1973.

Comber, Leon, Malaya's Secret Police 1945-1960: The Role Of The Special Branch In The Malayan Emergency, Singapore: Institute of South Asian Studies, 2008.

Dennis, Peter dan Grey, Jeffrey, Emergency and Confrontation: Australian Military Operations In Malaya and Borneo, 1950-1966, New South Wales: Allen \& Unwin In Association With The Australian War Memorial, 1996.

Ho Hui Ling, Pembanterasan Komunis Di Tanah Melayu, Kuala Lumpur: Penerbit Universiti Malaya, 2010.

Jackson, Robert, The Malayan Emergency: The Commonwealth's Wars 1948-1966, London: Routledge, 1991.

Mohd Azzam Hanif Ghows, The Malayan Emergency Revisited 1948-1960, Kuala Lumpur: AMR Holding Sdn Bhd, 2007.

Nyce, Ray, Chinese New Villages In Malaya: A Community Study, Singapura: Malaysian Sociological Research Institute, 1973.

R. Thambipillay, Little God's Arce 1948-1960, Ipoh: Perak Planter's Association Publication, 1998.

R. Thambipillay, The Malayan Police Force In The Emergency, 1948-1960, Perak: Goodturn Hoover Trading, 2003.

Yuen Yuet Leng, Operation Ginger, Kuala Lumpur: Vinpress Sdn. Bhd., 1998.

\section{Artikel}

Jayakumary Marimuthu, "Zaman Darurat, 1948-1960: Kajian Keadaan Sosioekonomi Di Sungai Siput (U)”, Malaysia dari segi Malaysia, Bil. 40, 2012.

King, John Kerry, “ Malaya's Resettlement Problem”, Far Eastern Survey, Vol. 23, No.3, 1954.

\section{Disertasi}

Mohd Razali bin Ya'acob@Jusoh, 'Home Guard di Perak, 1948-1960', Disertasi Sarjana, Jabatan Sejarah, Fakulti Sastera dan Sains Sosial, Universiti Malaya, Kuala Lumpur, 2016.

Shamsul Afkar bin Abd Rahman, 'History Of Special Operations Forces In Malaysia', Master Of Science In Defense Analysis, Naval Postgraduate School, California, 2013.

\section{Sumber Temubual}

Temubual dengan Datuk Dr. Leong Chee Woh, bekas Pegawai Cawangan Khas, di rumahnya di Seri Kembangan, Selangor pada 7 April 2019.

Temubual dengan Datuk Dr. Leong Chee Woh, bekas Pegawai Cawangan Khas, di rumahnya di Seri Kembangan, Selangor pada 26 Mei 2019. 